\title{
The Effect of Capital Structure, Profitability, and Activity Level to Stock Return
}

\author{
Eko Purwanto
}

Department of Psychology, Universitas Informatikadan Bisnis Indonesia, Bandung 40283, Indonesia. *Corresponding author. Email: Ekopurwanto@unibi.ac.id

\begin{abstract}
The study intends to test an impact of capital structure, profitability, and activity level to return stock. The capital structure to proxy with ratio leverage. The population used in this study is fifty firms having the largest market capitalization in Indonesia Stock Exchange. The firms as sample are taken from the population by using stratified random sampling. To select each indicator used to reflect each of stock return, capital structure, profitability, activity level factor analysis is used. After that, the regression model is used as the method of data analysis. The study concludes that profitability ratio have the positive impact on stock return whereas turnover ratio have the negative impact on firm value to proxy stock return. In addition, capital structure with leverage ratio do not have the impact on firm value to proxy stock return.
\end{abstract}

Keywords: Stuck return, Capital structure, Profitability, Turnover ratio

\section{INTRODUCTION}

The purpose of establishing a company is to achieve maximum profit, prosper the owner of the company or shareholders and maximize the value of the company as reflected in stock returns. Determination of company goals is directly related to measuring company performance. Errors in performance measurement will result in errors in assessing performance related to the objectives set for all interested parties [1]. The better the financial performance of a company, the more investor interest in the demand for shares increases, which then impacts on the stock itself. Financial performance is an analysis carried out to see the extent to which a company has implemented financial implementation rules properly [2]. Financial performance is related to financial analysis that involves the use of various elements of financial statements [3]. Financial statements can be measured using financial ratios. Financial ratios are indexes that connect accounting data and are obtained by dividing one number by another [4]. Capital structure is used to measure how much the company is financed by debt [5]. Creditors prefer low debt. The lower the debt, the higher the level of funding provided by shareholders and the greater protection for creditors in the event of large losses [6]. The results of research on ref [7] show that capital structure affects stock returns. In contrast, on ref [8] show that capital structure has no effect on stock returns.

Profitability is defined as the company's ability to earn profits from all existing sources, sales, cash, assets and capital [8]. The results of research on ref [9]. Pprofitability affects stock returns. In contrast, research on ref [10]. document that profitability has no effect on stock returns. The activity ratio, also known as the efficiency or turnover ratio, measures how effectively the company uses its various assets [11]. In relation to the effect of the company's activity ratio on stock returns, the results of research on ref [12]. show that the activity ratio has an effect on stock returns, while the results of research on ref [13]. show that the activity ratio has no effect on stock returns. Based on the inconsistency of the results of previous studies, the researcher wishes to conduct similar studies in different ways. 


\section{RESEARCH MODEL}

\subsection{Research Model}

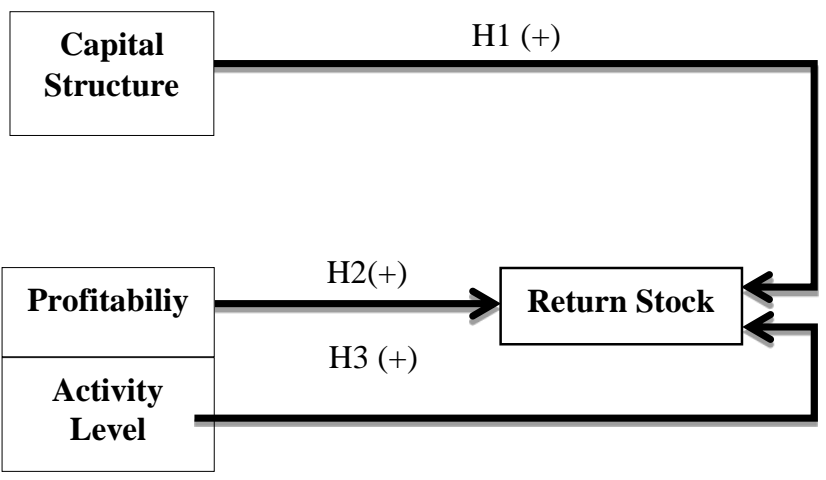

Figure 1 Research Model

Based on the background previously described, the researcher has the following hypothesis:

H1: Capital structure affects stock returns

H2: Profitability affects stock returns

H3: The level of activity has an effect on stock returns

\section{METHODOLOGY}

Population is the totality of all objects / individuals that have certain, clear, and complete characters to be studied. Objects or values are called units of analysis or population elements [14]. The population used in this study are all non-financial companies listed on the Indonesia Stock Exchange from 2014 to 2018.

Samples are part of the population taken in certain ways which also have certain, clear, and complete characteristics which are considered to be representative of the population. The object or value to be studied in the sample is called the sample unit [14]. The sampling process must be able to produce accurate and precise samples. Samples that are inaccurate and inaccurate will provide unexpected research conclusions or may result in misleading conclusions [15]. The sampling technique used in this study was probability-based sampling with stratified random sampling method. Complete information regarding the strata and number of issuers as stratum members along with the number of samples that have achieved the number of strata can be seen in Table 1 .

Based on the number of sample frames of 24 companies, a representative number is determined. Based on the Slovin formula, 23 issuers were selected to be the research sample. The company name can be seen in Table 2 as follows.
Table 1. The number of samples that represent the sample frame based on the stratification random sampling method

\begin{tabular}{|c|c|c|c|}
\hline Sector & $\begin{array}{c}\text { Number of } \\
\text { sample frames } \\
(\mathrm{N})\end{array}$ & $\%$ & $\begin{array}{l}\text { Number of } \\
\text { sample (n) }\end{array}$ \\
\hline Primary & 5 & 20.83 & 5 \\
\hline Secondary & 11 & 45.83 & 10 \\
\hline Tertiary & 8 & 33.33 & 8 \\
\hline Total & 24 & 100 & 23 \\
\hline
\end{tabular}

Table 2. Issuer Name Selected as Research Sample

\begin{tabular}{|c|c|c|c|}
\hline No. & $\begin{array}{l}\text { Code } \\
\text { Emitted }\end{array}$ & Name Emitted & Sector \\
\hline 1. & ADRO & PT Adaro Energy Tbk. & Primary \\
\hline 2. & BYAN & $\begin{array}{l}\text { PT Bayan Resources } \\
\text { Tbk. }\end{array}$ & Primary \\
\hline 3. & PTBA & 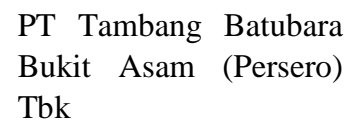 & Primary \\
\hline 4. & INCO & PT Vale Indonesia Tbk. & Primary \\
\hline 5. & AALI & $\begin{array}{l}\text { PT Astra Argo Lestari } \\
\text { Tbk. }\end{array}$ & Primary \\
\hline 6. & ASII & $\begin{array}{l}\text { PT Astra International } \\
\text { Tbk. }\end{array}$ & Secondary \\
\hline 7. & UNVR & PT Unilever Tbk. & Secondary \\
\hline 8. & HMSP & $\begin{array}{l}\text { PT Hanjaya Mandala } \\
\text { Sampoerna Tbk }\end{array}$ & Secondary \\
\hline 9. & UNTR & PT United Tractors Tbk. & Secondary \\
\hline 10 & GGRM & PT Gudang Garam Tbk. & Secondary \\
\hline 11. & INTP & $\begin{array}{l}\text { PT Indocement Tunggal } \\
\text { Prakarsa Tbk. }\end{array}$ & Secondary \\
\hline 12. & SMGR & $\begin{array}{l}\text { PT Semen Indonesia } \\
\text { (Persero) Tbk. }\end{array}$ & Secondary \\
\hline 13 & INDF & PT Indofood Tbk. & Secondary \\
\hline 14 & CPIN & $\begin{array}{l}\text { PT Charoen Pokphand } \\
\text { Indonesia Tbk. }\end{array}$ & Secondary \\
\hline 15. & ICBP & $\begin{array}{l}\text { PT Indofood CBP } \\
\text { Sukses Makmur Tbk }\end{array}$ & Secondary \\
\hline 16. & TLKM & $\begin{array}{l}\text { PT Telekomunikasi } \\
\text { Indonesia (Persero) } \\
\text { Tbk. }\end{array}$ & Tertiary \\
\hline 17. & PGAS & $\begin{array}{l}\text { PT Perusahaan Gas } \\
\text { Negara (Persero) Tbk. }\end{array}$ & Tertiary \\
\hline 18. & EXCL & PT XL Axiata Tbk & Tertiary \\
\hline 19. & ISAT & PT Indosat, Tbk. & Tertiary \\
\hline 20. & JSMR & $\begin{array}{ll}\text { PT Jasa } & \text { Marga } \\
\text { (Persero), Tbk }\end{array}$ & Tertiary \\
\hline 21. & LPKR & PT Lippo Karawaci Tbk & Tertiary \\
\hline 22. & SMAR & SMART Tbk. & Tertiary \\
\hline 23. & $\mathrm{MNCN}$ & $\begin{array}{l}\text { PT Media Nusantara } \\
\text { Citra Tbk }\end{array}$ & Tertiary \\
\hline
\end{tabular}


The data collection method used in this study is a secondary method. secondary sources are sources that do not directly provide data to data collectors. The following is a classification of secondary sources:

a. Internal sources

In this study, the company's financial statements are an internal source used by the author to conduct research. The company's financial reports are obtained from www.idx.co.id.

b. External sources

In this research, external sources are text books in libraries, internet, scientific journals and others.

\section{RESULT AND DISCUSSION}

Factor analysis identifies the structure of the relationship between variables or respondents by looking at the correlation between variables or the correlation between respondents. Factor analysis summarizes the information contained in the original variable into a new set of dimensions or variants (factor / component) [16]. The purpose of the factor analysis is to select the best indicators that reflect the research variables. This study uses factor analysis to select indicators that reflect the variables used (stock returns, profitability, capital struckture / leverage, and activity ratios). The initial results of the factor analysis can be seen in Table 3. It can be seen that the KMO Measure of Sampling Adequacy value is 0.584 . This value is greater than the value required by Ghozali (2016), which is 0.5 , which means that the size of the observation is sufficient and the results of the factor analysis can be continued at a later stage.

Table 3. Kaiser-Meyer-Olkin and Bartlett's Test

\begin{tabular}{lll}
\hline $\begin{array}{l}\text { Kaiser-Meyer-Olkin Measure of Sampling } \\
\text { Adequacy. }\end{array}$ & .584 \\
& Approx. & \\
Bartlett's Test f & Chi-Square & 2.461 .760 \\
Sphericity & Df & 153 \\
& Sig. & .000 \\
\hline
\end{tabular}

The next step is to determine the minimum and maximum values, mean and standard deviation of the indicators that best reflect each research variable. The descriptive statistics on these indicators can be seen in Table 4.

Table 4. Descriptive Statistics

\begin{tabular}{lccccc}
\hline Variable & $\mathbf{N}$ & Minimum & Maximum & Mean & $\begin{array}{c}\text { Std. } \\
\text { Deviation }\end{array}$ \\
\hline ROE & 115 & -73.97 & 125.81 & 270.994 & $2,736,785$ \\
DAR & 115 & .13 & 1.21 & .4430 & .17059 \\
ITO & 115 & .30 & 602.25 & 590.277 & $13,190,644$ \\
Return & 115 & .26 & 4.48 & 11.996 & .51131 \\
Stock & & & & & \\
\hline
\end{tabular}

The classical assumption test is a statistical requirement that must be met in multiple linear regression analysis based on ordinary least square (OLS) [17]. In this study, the classical assumption test was carried out successively, namely the multicollinearity test, heteroscedasticity test, autocorrelation test, and normality test. Table 4.4 presents the results of multicollinearity detection based on the Variance Inflation Factor (VIF) value. Based on the table, there is no Variance Inflation Factor (VIF) value for the independent variable that is greater than 10 . Thus, it can be said that multicollinearity between independent variables does not occur in the regression model.

Table 5.Multicollinearity detection result

\begin{tabular}{lcc}
\hline Independent & \multicolumn{2}{c}{ Collinearity Statistics } \\
\hline Variable & Tolerance & VIF \\
ROE & .830 & 1.205 \\
DAR & .753 & 1.328 \\
ITO & .863 & 1.158 \\
\hline
\end{tabular}

Table 6 is the result of the heteroscedasticity test with the White test. Seen in the table, the value of Prob. Chi-Square (6) is greater than $\alpha$ by $5 \%$. This shows that heteroscedasticity does not occur.

Table 6 The result of the heteroscedasticity test

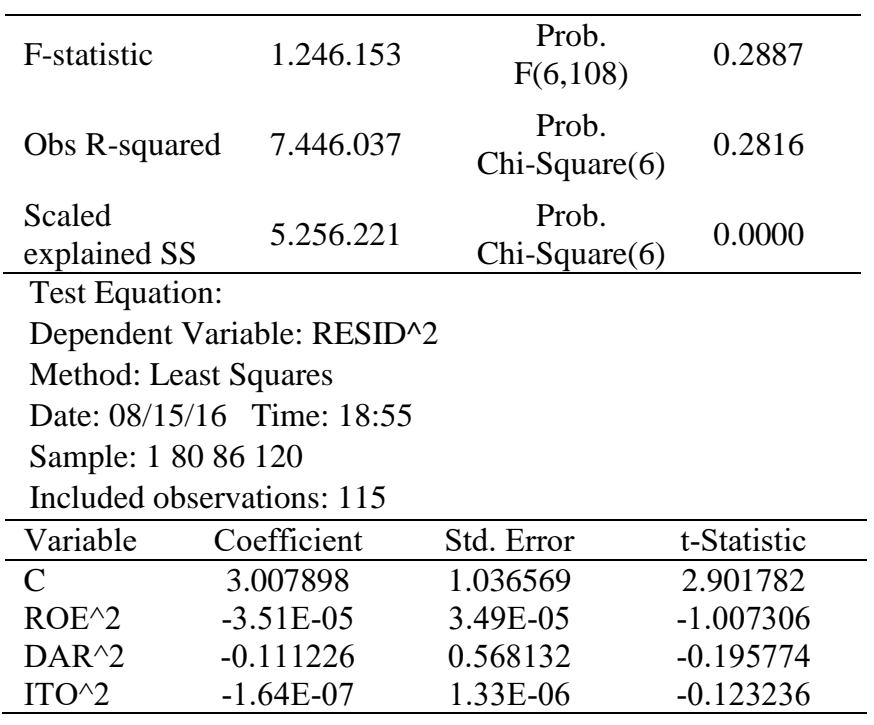

Autocorrelation Test Table 7 shows a table that shows the Durbin-Watson statistical value based on the results of data processing with the IBM SPSS 20 Program. In this table, the DW value is 1.951. Furthermore, this value is compared with the decision making criteria whether there is autocorrelation as presented in Table 7. By using a significance level $(\alpha)$ of $5 \%$ on the number of observations (n) of 115 and 6 independent variables $(\mathrm{k})$, the $\mathrm{dU}$ value is 
1.805 and the $4-\mathrm{dU}$ value is $4-1,805=2.195$. It can be seen that the DW value is between the $\mathrm{dU}$ and 4-dU values so that the null hypothesis which states that there is no autocorrelation is fully acceptable.

Table 7. Durbin Watson Statistic

\begin{tabular}{lcccc}
\hline $\mathrm{R}$ & $\begin{array}{c}\mathrm{R} \\
\text { Square }\end{array}$ & $\begin{array}{c}\text { Adjusted } \\
\text { R Square }\end{array}$ & $\begin{array}{c}\text { Std. Error of } \\
\text { the Estimate }\end{array}$ & $\begin{array}{c}\text { Durbin- } \\
\text { Watson }\end{array}$ \\
\hline $.315^{\mathrm{a}}$ & .099 & .049 & .49862 & 1.951 \\
\hline
\end{tabular}

a. Predictors: (Constant) ROE, DAR, ITO

b. Dependent Variable: Return Stock

Table 8 presents the results of the calculation of the $\mathrm{Z}$ value using the Kolmogorov-Smirnov method along with the asymp value. Sig. (2-tailed) of the $\mathrm{Z}$ value. Seen in that, the asymp value. Sig. (2-tailed) of 0.026 . Furthermore, this value is compared with $\alpha$ of $5 \%$. Because the asymp value. Sig. (2-tailed) is less than $\alpha$ by $5 \%$ then based on $\mathrm{Ha}$ is accepted. Thus, the regression model residual data are not normally distributed.

Table 8. Normality Test Results with the KolmogorovSmirnov Test

\begin{tabular}{lll}
\hline & & Unstandardized Residual \\
\hline $\mathrm{N}$ & Mean & 115 \\
Normal & Std. & $0,00 \mathrm{E}+00$ \\
Parameters & Deviation & .48531892 \\
Most Extreme & Absolute & .137 \\
Differences & Positive & .137 \\
& Negative & -.119 \\
Kolmogorov-Smirnov Z & 1.472 \\
Asymp. Sig. (2-tailed) & .026 \\
\hline
\end{tabular}

a. Test distribution is Normal.

b. Calculated from data.

Residuals that are not normally distributed are caused by outliers, outlier value is still found if the absolute value of the standard residual exceeds 2 and to obtain residuals that are normally distributed, the observational data containing outliers is not used in the model. This process is carried out continuously and stops when no outliers are found at a certain stage. It turns out that with the issuance of observational data containing these outliers, the R-square value has increased from stage to stage (see Table 9).

After all outliers were detected and no longer used in forming the research model, the normality test was performed again (see Table 9). Seen in the table, the asymp value. Sig. (2-tailed) of 0.485 . This value is greater than $\alpha$ by $5 \%$. Thus, the residual data are normally distributed.
Table 9. Outlier Detection and Change in R-Square Value

Panel A. Data number which becomes an outlier on each Outlier Stage

\begin{tabular}{lllll}
\hline Step 1 & Step 2 & Step 3 & Step 4 & Step 5 \\
\hline 16 & 8 & 83 & 23 & 31 \\
41 & 36 & 106 & 108 & \\
66 & 43 & & & \\
111 & 96 & & & \\
& 113 & & & \\
\hline
\end{tabular}

Panel B. R-square value after outlier detection at each stage

\begin{tabular}{lllll}
\hline Step 1 & Step 2 & Step 3 & Step 4 & Step 5 \\
\hline 0.117 & 0.142 & 0.166 & 0.310 & 0.318 \\
\hline
\end{tabular}

Table 10. Results of Normality Test with the KolmogorovSmirnov One-Sample Test after Outlier Detection

\begin{tabular}{llc}
\hline & & Unstandardized Residual \\
\hline $\mathrm{N}$ & Mean & 101 \\
Normal & Std. & $0,00 \mathrm{E}+00$ \\
Parameters & Deviation & .19416444 \\
& Absolute & .083 \\
Most & Positive & .067 \\
Extreme & Negative & -.083 \\
Differences & .837 \\
Kolmogorov-Smirnov Z & .485 \\
Asymp. Sig. (2-tailed) &
\end{tabular}

a. Test distribution is Normal.

b. Calculated from data.

Table 11 is the estimation result of the regression model after outliers were not used in the research model. In other words, this regression model is an estimation result after fulfilling all the classical assumption tests including the normality test.

Table 11 is the estimation result of the regression model

\begin{tabular}{lccccc}
\hline Independent & \multicolumn{2}{c}{$\begin{array}{l}\text { Unstandardized } \\
\text { Coefficients }\end{array}$} & $\begin{array}{c}\text { Standardized } \\
\text { Coefficients }\end{array}$ & $\mathrm{t}$ & Sig. \\
\hline Variable & $\mathrm{B}$ & $\begin{array}{c}\text { Std. } \\
\text { Error }\end{array}$ & Beta & & \\
(Constant) & .391 & .481 & n.a. & .812 & .419 \\
ROE & .004 & .001 & .460 & 4.521 & .000 \\
DAR & -.208 & .143 & -.156 & -1.462 & .147 \\
ITO & .000 & .000 & -.192 & -2.050 & .043 \\
\hline
\end{tabular}




\section{CONCLUSION}

The first hypothesis regarding capital structure states that leverage has a negative effect on stock returns. In Table 11, you can see the Sig. on DAR of 0.147 . Given the Sig. If this variable is greater than $\alpha$ of $5 \%$, the capital structure / leverage in DAR has no effect on stock returns. The second hypothesis states that profitability has a positive effect on stock returns. In Table 11, you can see the Sig. ROE of 0,000 and the regression coefficient estimation results show a positive sign. Given the Sig. on this variable is greater than $\alpha$ by $5 \%$, then profitability has a positive effect on stock returns. The third hypothesis states that the company's activity ratio has a positive effect on stock returns. In Table 11, you can see the Sig. on ITO of 0.043 and the expectation of the regression coefficient sign shows a negative result. Given the Sig. on this variable is less than $\alpha$ by $5 \%$, then company activity has a negative effect on stock returns.

\section{REFERENCES}

[1] B. Bidani, M. Ravallion, A regional poverty profile for Indonesia. Bulletin of Indonesian Economic Studies, 29 (3) (1993), 37-68. DOI: https://doi.org/10. $1080 / 00074919312331336451$

[1] R. Bhagwat, M. K. Sharma. Performance measurement of supply chain management: A balanced scorecard approach. Computers \& industrial engineering, 53 (1) (2007) 43-62. DOI: https://doi.org /10.1016/j.cie.2007.04.001

[2] S.Brammer, A. Millington. Does it pay to be different? An analysis of the relationship between corporate social and financial performance. Strategic management journal, 29 (12) (2008) 1325-1343. DOI: https://doi.org/10.1002/smj.714

[3] C. Spathis, M. Doumpos, C. Zopounidis. Detecting falsified financial statements: a comparative study using multicriteria analysis and multivariate statistical techniques. European Accounting Review, 11(3) (2002) 509-535. DOI: https://doi.org/10.1080/0963818022 000000966

[4] Edmister, R. O. (1972). An empirical test of financial ratio analysis for small business failure prediction. Journal of Financial and Quantitative analysis, 1477-1493. DOI: https://doi.org/10.2307/232 9929

[5] G. Huang. The determinants of capital structure: Evidence from China. China economic review, 17 (1) (2006) 14-36. DOI: https://doi.org/10.1016/j.chieco.20 05.02 .007
[6] S. Khalil, S. Mansi, M. Mazboudi, A. J. Zhang. Information asymmetry and the wealth appropriation effect in the bond market: Evidence from late disclosures. Journal of Business Research, 95 (2019) 49-61. DOI: https://doi.org/10.1016/j.jbusres.2018.09. 022

[7] N. A. Ramli, H. Latan, G. T. Solovida. Determinants of capital structure and firm financial performance-A PLS-SEM approach: Evidence from Malaysia and Indonesia. The Quarterly Review of Economics and Finance, 71 (2019) 148-160. DOI : https://doi.org/10.1016/j.qref.2018.07.001

[8] A. Assagaf, E. Murwaningsari, J. Gunawan, S. Mayangsari. The Effect of Macro Economic Variables on Stock Return of Companies That Listed in Stock Exchange: Empirical Evidence from Indonesia. International Journal of Business and Management, 14 (8) (2019) 108-116. DOI: https://doi.org/10.9734/ajeb $\mathrm{a} / 2019 / \mathrm{v} 11 \mathrm{i} 230124$

[9] N. Idamanti. Pengaruh Likuiditas, Profitabilitas dan Penjualan Terhadap Harga Saham Perusahaan Makanan dan Minuman yang Tercatat di Bursa Efek Indonesia Tahun 2010-2014. Manajemen Bisnis, 6 (2) (2018). DOI : https://doi.org/10.22219/jmb.v6i2.5538

[10] P. E. D. M. Dewi. Pengaruh Rasio Likuiditas, Profitabilitas, Solvabilitas, Aktivitas Dan Penilaian Pasar Terhadap Return Saham. JIA (Jurnal Ilmiah Akuntansi), 1 (2) (2017) DOI: http://dx.doi.org/10.23 887/jia.v1i2.9988

[11] T. N. Nariswari, N. M. Nugraha. Profit Growth: Impact of Net Profit Margin, Gross Profit Margin and Total Assests Turnover. International Journal of Finance \& Banking Studies (2147-4486) 9 (4) (2020) 87-96. DOI : https://doi.org/10.20525/ijfbs.v9i4.937

[12] R. Trisnawati, M. Mardayaningrum, L. Khotimah. Determinan manajemen laba akrual pada indeks LQ45 dan JII periode 2010-2015. Riset Akuntansi dan Keuangan Indonesia, 3 (2) (2018) 141-151. DOI : 10.23917/reaksi.v3i2.6702

[13] H. L. Mufidah, D. F. Azizah. Pengaruh Rasio Aktivitas Dan Rasio Leverage Terhadap Profitabilitas (Studi pada Perusahaan Sub Sektor Food and Beverages yang terdaftar di BEI Periode (2012-2016). Jurnal Administrasi Bisnis, 59 (1) (2018) 1-7. 
[14] A. L. Braitman, A. R. Battles, M. L. Kelley, H. C. Hamrick, R. J. Cramer, S. Ehlke, A. J. Bravo. Psychometric properties of a Modified Moral Injury Questionnaire in a military population.Traumatology, 24 (4) ( 2018) 301. DOI : https://doi.org/10.1037/trm0 000158

[15] M. J. Harvey, P. Sperlich, T. J. Clough, F. M. Kelliher, K. L. McGeough, R. J. Martin, R. Moss. Global Research Alliance N2O chamber methodology guidelines: Recommendations for air sample collection, storage, and analysis. Journal of Environmental Quality, 49 (5) (2020) 1110-1125. DOI : https://doi org/10.1002/jeq2.20129

[16] S. Wahyudi, H. Hasanudin, I. Pangestutia. Asset allocation and strategies on investment portfolio performance: A study on the implementation of employee pension fund in Indonesia. Accounting, 6 (5) (2020) 839-850.DOI: 10.5267/j.ac.2020.5.010

[17] R. Sijabat. Gender Difference On The Modeling Of Turnover Intention Behavior. Fokus Ekonomi: Jurnal Ilmiah Ekonomi, 15 (1) (2020) 167-182. DOI : https://doi.org/10.34152/fe.15.1.167-182 